UDC $81 ' 1: 327=111$

https://doi.org/10.31548/philolog2021.03.107

\title{
A COMPARATIVE ANALYSIS OF LANGUAGES IN THE AREA OF INTERNATIONAL RELATIONS
}

\author{
S. B. KHRYSTIUK, PhD in World History, Associate Professor, \\ National University of Life and Environmental Sciences of Ukraine \\ E-mail: svitlana.khrystiuk@gmail.com \\ http://orcid.org/0000-0003-4119-8562

\begin{abstract}
O. O. SHCHUKA, bachelor of International Relations, National University of Life and Environmental Sciences of Ukraine

E-mail: lesusuk74@gmail.com
\end{abstract}

\begin{abstract}
The current study is aimed at the international languages' detailed examining and comparative analysis in the area of International relations and diplomacy in chronological order. It has proved that in language analysis, there are many variables that must be taken into the deep account; the most principal ones are the homogenous or heterogeneous population structure, cultural heritage of the state, and culture of language learnt, different techniques and strategies in learning situations. The study highlights the fact that international relations appeared in the $X-I X$ centuries $B C$ and developed quite a long time and dynamically; their rapid development reason was the need for food and slave trade. Subsequently, diplomacy became a tool for resolving conflicts peacefully. International relations began in Greece and Rome; thus, the first language for conducting negotiations was Latin, however, we must admit that a language itself was often the cause of misunderstandings and conflicts. At one point it was replaced by French due to Napoleon's vast lands seizure and later by English after the Paris Peace Conference, at which English and French were equalized. The UN meeting has approved several international languages English, French, Spanish, Russian, and Chinese, but they are considered to be only international ones. Undoubtedly, diplomatic language is a great art of speaking, writing, and resolving some problems at issue. Comparing the number of people and language importance, we may conclude that native speakers do not make the language international. Easiness to learn and similarity to other languages are the distinguishing features required to become international.

It's worth noting that the language learning simplicity as well as the speakers' mentality does not affect the language social significance directly.

There has been turned out that the global map of language influence has a hierarchical structure: the central axis of communications (hub) - English, surrounded by second-order hubs: German, French, Spanish, Russian and Portuguese. It is believed that the oldest written treaty was a treaty concluded in 1296 $B C$ between Pharaoh Ramses II and King Hatgushil III. The current study has determined communication and international relations as common denominators and reached the conclusion that diplomatic language is characterized not only by the fact of description accuracy, an in-depth analysis of government policy and actions, but also precise and concise wording.
\end{abstract}

Keywords: comparative analysis, international (global) language, international relations, diplomatic language, negotiations, accuracy, distinguishing features.

Introduction. The struggle for language has long been a problem for many countries. Everyone, without exception, dreamed that their language would become international. According to the language comparative analysis requirements, the exploratory study has been conducted and compared the different countries history. In the course of the study there has been discovered that if a country has a great influence (and it does not always depend on the territory, but more often on economic power and great culture influence) on others, then the language becomes dominating in the world.

Having read a large number of articles by various authors from many different countries, we can state that each of them wants their language to be international. Having asked a lot of acquaintances from different countries if they were satisfied with the fact that most people now study English as an international language, most of them don't oppose this fact, but they would be happy if their language became more influential and powerful tool for conducting both domestic and foreign affairs.

This linguistics' direction has not yet been developed, that's why it's quite obvious to make an attempt to denote its main features. Distinguishing factors between international languages that increase the language social significance to the international level (its global authority) are, for example, the following: 1) territorial distribution and passion-migration activity of the people (Bantu [ethnic explosion of the beginning of the III millennium BC simultaneously with Indo-Europeans and Austronesians]; Hindus AD]; Polynesia, Slavs, 
Romance; Germans, Turks, Arabs); 2) military might, political power and dominance over other peoples (Romans, Persians, Chinese; Arabs, Russians, Turks, Spaniards, Portuguese, British, Dutch); 3) native speakers' trade (Greeks, Chinese, Jews, Aramaeans, Persians, Arabs); 4) availability of technological, cultural and scientific achievements (Sumerians, Greeks; French, Dutch, Germans, British); 5) distribution of religious literature or writing system (Sumerians, Akkadians, Greeks, Romans, Arabs, Russians). Although Arabic, Chinese, and Hindi are considered far more important international languages, they are spoken by far more people than, for example, German or Russian - in cultural significance, they are significantly inferior to the latter. Statistically and culturologically promising option is the construction of international vocabulary and international language on the basis of Latin and Sanskrit.

The objective of the study is to identify similar and distinctive features, find both general and specific points, factors distinguishing between international (global) languages and languages between nations or languages of international relations in the context of conducting international affairs, their comprehensive analysis and scientific prognosis regarding their theoretical as well as practical significance.

Methods of study. During the study, the following methods of cognition were used: historicism, consistency, objectivity, chronological sequence, generalization, systematization, analysis and synthesis, comparison, classifications, etc. The analysis method essentially involves paraphrasing the linguistic routines in a meta-language based on intuitively intelligible natural language, and in simple terms which permit a precise comparison of both the similarities and differences between the items in the two languages. Thus, similarities and differences have been established using comparative-historical, synchronic-comparative, system and synchronicdiachronic analysis, comparison methods.

Analysis of the latest studies and publications. Studies of English as an international language are actively developing in the late twentieth - early twenty-first century due to the rapid spread of the language through the Internet. Researcher S. Karasov studied English in terms of language, which is able to accumulate national characteristics of language use. Linguist D. Crystal [9] studies English as an international (global) language in the context of business communication, Ye. Sokur, R. Svyrydon, V. Mamontov, Z. Gabunia, Ye. Ulimbasheva [1], E. Pasiv, S. Shatylov and G. Lozanov, highlights on the increasing popularity of English due to the influence of the English language globalization on international communication. Both theoretical and practical backgrounds of language comparative analysis in the area of International relations have been laid by Felix Ameka [10], K. Zakiryanov [2], $\mathrm{H}$. Anderson, C. Webber and others. H. Burhanudeen [8], Lord Brimelow, D. Crystal, N. Kashchyshyn [3], E. Kuzmin [4], P. Sardachuk, O. Kulyk [6], O. Sahaidak [5] have paid their particular attention to the English language as a language of diplomacy.

Results. The slave-owning city-states' foreign policy was determined by interests of struggle for territorial expansion, acquisition of slaves, markets. Hence, the desire for hegemony, allies search, formation of groups, colonial expansion, aimed at forming great powers and emerging clashes between the Greeks in the East, with the Persian Empire, the Romans - in the West, with the richest trading republic of the ancient world - Karf. The ancient city-state diplomatic activities were expressed in negotiating on strategically vital issues, the continuous embassy exchange, the meetings convening, concluding defense and offensive alliance agreements. The diplomacy of classical Greek states during the Peloponnesian War between the two largest military-political alliances - Athens and Spartan - that had been fighting for supremacy in the Hellenic world for 30 years. Later, no less intense diplomacy was intensified with the new force emergence on the Greek arena - the Kingdom of Macedonia, embodying the unified tendencies of Greece at the time, combined with colonial expansion to the east.

It is believed that the oldest written treaty was a treaty concluded in $1296 \mathrm{BC}$ between Pharaoh Ramses II and King Hatgushil III. It established peace between the two states and formed a military alliance, which provided for mutual assistance in the event of war with third states, in the suppression of internal uprisings, as well as the extradition of defectors. The text of the agreement was written on silver plates, and both copies were sealed with signatures and state seals. It has already been noted that in the practice of international relations the common language was originally Latin, because the treaties were concluded more often by the Greeks or Romans with other states, because they were considered the most developed kingdom, empire. Thus, the Latin language has become indispensable for those people who study law. The reason is that a large number of the first terms were composed in Latin and had no translation.

French, as a language of written communication, was formed in 842 from the vernacular Latin and departed from it further than any other Romance language. The decisive moment in the French language history was 1539 , when by order of Ville-Cottret the Paris people's dialect was approved as the official national language.

Today, French is represented not only in its historical homeland - France, but also in other 
countries on the globe, performing the functions of international communication. About 90 million people in the world now use it as a native language. In recent years, the number of people speaking French has increased significantly, and together with those who actively use it as a second language, the total number of Francophones is more than 220 million. The modern French-language map of the world shows that French is the sixth most common language in the world (after Chinese, English, Hindi, Spanish and Arabic). It is the official language of 32 countries and the fifth largest ones in the world.

Being the second international relations' language, the official diplomatic language, French is both the official and working language of all European and most international organizations. Among them it's worth distinguish the UN, the UNESCO, the European Union, the Council of Europe, the NATO, the International Olympic Committee, the World Trade Organization, the International Committee of the Red Cross. All diplomatic notes of the Vatican are composed in this language.

At the Vienna Congress in 1815 and the Paris Congress in 1856, all work was conducted exclusively in French. Only at the Paris Conference of 1918-1919 there was the English language equal in rights to French: "This treaty, as the article on the Treaty of Versailles ratification shows, is authentic both in French and English texts." It was the article that put an end to the French language's claims to obtaining the status of the official diplomatic language. Apparently, this was inevitable, because it is obvious that the French language supremacy gave French diplomats an advantage over their competitors. It can be argued that today the French language importance as the international communication language, democracy and culture is growing in the world. With the general trend towards economy globalization and culture unification, only the struggle to preserve the diverse linguistic heritage will help preserve the uniqueness of the world space. The moment when the French language may lose its significance will never come!

In the twentieth century, we notice the emergence of English as a second, and later as the main diplomacy language. At a conference in San Francisco in 1945, five languages were adopted for official communication: Chinese, English, French, Russian, and Spanish.

From a historical perspective, globalization of the English language can be clearly explained. In essence, English, originating from the West Germanic dialect spoken by the English and Saxon tribes, spread to the south-east of Scotland through the Anglo-Saxon Kingdom. Later, English in the colonial regime of the United Kingdom became a common language in the British Empire colonies. The newly formed peoples also began to speak English to avoid political difficulties. Finally, as a result of the British Empire rise, the language spread to North America, India, Africa, Australia and many regions. The English language hegemony, which began in the mid-twentieth century in the United States, accelerated the spread of this language in the world. It appeared in America in the seventeenth century in the English-speaking British Colonies, formed from immigrants who arrived to North America.

According to statistics, about a quarter of the world's population has already been speaking English rapidly, and this figure is growing: by the beginning of the twenty-first century, it was more than one and a half billion people. No other language, both in terms of speed and scale of distribution, can compare with English. In today's world, 750 million people use English as a second language. Many companies are increasing the number of language trainings for their employees in mastering English for professional purposes. English writer Robert McCram in his work "The English story" emphasizes that from ancient times and today the English language includes many words from other languages. According to the writer, many borrowed words in English are considered the main reason of its recognition in the world. As a means of communication №1 in Europe, English is used not only in countries where it has the status of state language, but also among peoples (France, Portugal, Italy, Spain, Sweden, Norway, etc.).

The Chinese language is the most important representative of the Sino-Tibetan language family. It is spoken by at least $90 \%$ of China's population, that is more than a billion people, and is also common in Indonesia, Cambodia, Laos, Vietnam, Myanmar, Malaysia, Thailand, Singapore and other countries - an estimated 1989 Chinese-speaking population, language outside of "Greater" China, which includes Taiwan, Macao and Hong Kong, was about 50 million. Chinese literacy age is used in such a neighboring country as China and Japan, a language that is not related to Chinese. Chinese is mostly characterized by three or four types of tones, monosyllabism of almost all simple words and almost complete absence of word-changing affixes. There are currently about 110 million people in the world who speak Chinese fluently, however, mostly are Chinese, or people from neighboring countries. Due to the fact that this language has a very complex phonetics, most people do not dare to learn it. In addition, spelling is not easy either, which is why agreements in this language are concluded only with those countries that agree to it.

Diplomatic language, both official and especially the language of international politics, differs significantly from journalistic, sometimes emotional, verbose; it differs to some extent from 
the literary, more figurative, and free. Although a good command of the literary language helps a diplomat. Pushkin's language of prose comes closest to the diplomatic language - concise, accurate, without whimsy. "Diplomacy is the science of writing." In this context, it's worth noting that written language play more important role than oral. Diplomatic language is characterized not only by the description accuracy, an in-depth analysis of government policy and actions, but also precise and concise wording, so that, as the classic taught, "words were close and thoughts were spacious." Therefore, those who do not have the gift of the written word or have not developed the skills of diplomatic style; it is hardly advisable to go to diplomats. The content of diplomatic documents is set, established (by the relevant government body that determines the policy) before the diplomatic document drafting begins. Hence, it is clear how important are language instruments, word accuracy, each phrase correspondence with the meaning embedded in it.

\section{Список використаних джерел}

1. Габуніа 3., Улімбашева Е. Міжкультурна комунікація як фракт мови : навчальний посібник зі спецкурсу «Міжкультурна комунікація». Львів, 2005. $176 \mathrm{c}$.

2. Закирьянов К. Сопоставительное исследование разноструктурных языков: лингвометодический аспект. Российский гуманитарный журнал. 2015. Выпуск 4 (3).С. 224233.

3. Кащишин Н. Особливості дипломатичної мови : історія і сьогодення. [Електронний ресурс]. Режим доступу: https://everest-center.com/osoblivostidiplomatichnoyi-movi-istoriya-i sogodennya/

4. Кузьмин Э. Л. Протокол и этикет дипломатического и делового общения. М.: Юридический колледж МГУ, 1996. 381 с.

5. Сагайдак О. Дипломатичний протокол та етикет. Київ: Знання, 2006. 380 с.

6. Сардачук П., Кулик О. Дипломатичне представництво : організація і форми роботи. К.: Україна, 2001. 176 с.

7. Сафонов М. Китайский язык и китайская письменность : курс лекций. М.: АСТ, ВостокЗапад, 2007.640 c.

8. Burhanudeen $H$. Diplomatic language: an insight from speeches used in international diplomacy. Journal of Southeast Asia Social Sciences and Humanities "Akademika", 2006. Vol. 67. No 1. P. 37-51.

9. Crystal D. Front matter. In English as a Global Language. N. Y.: Cambridge University Press, 2012. 224 p.

10. Felix K Ameka. A comparative analysis of linguistic routines in two languages: English and ewe. Journal of Pragmatics, 1987. No. 11 (3). P. 299-326.
Discussion. Thus, having analyzed the huge amount of data we can conclude that today there is no mandatory common language for official diplomatic relations

and international treaties (in the past, Latin and then French dominated). The principle of language equality is gradually being approved. With rare exceptions, public foreign bodies conduct official correspondence, especially the exchange of diplomatic documents, in their national languages.

Currently, for the convenience of both parties, agreements are signed in two or even three languages. The institutional nature and clichédness of diplomatic language are skillfully combined with the emotionality of statements, and the word remains the main way of influence and confrontation. Diplomatic language will always be needed by countries, because no politician in his career has done without agreements. And the ability to set the right conditions is definitely needed.

11.Stanko Nick. Use of language in diplomacy. [Електронний ресурс]. Режим доступу: https://www.diplomacy.edu/sites/ default/ files/Language_Diplomacy_Chapter2.PDF

\section{References}

1. Habunia, Z., Ulimbasheva, Ye. (2005). Mizkulturna komunikatsiia yak fakt movy [Crosscultural communication as a language fact]. Lviv, 176. [In Ukrainian].

2. Zakyrianov, K. (2015). Sopostavitelnoie issledovaniie raznostrukturnykh yazykov: linhvometodicheskiy aspect. [Comparative study of languages of different structures: linguistic and methodological aspect]. Rossiyskiy humanitarnyi zhurnal. [Russian Humanitarian Journal]. Vol. 4 (3). 224-233. [In Russian].

3. Kashchyshyn, N. (2017). Osoblyvosti dyplomatychnoi movy : istoriia i sohodennia. [Specifics of diplomatic language: history and the present]. URL: https://everest-center.com/osoblivostidiplomatichnoyi-movi-istoriya-i-sogodennya/

4. Kuzmin, E. (1996). Protokol i etiket diplomaticheskoho i delovoho obshcheniia. [Protocol and etiquette of diplomatic and business communication]. Moscow : College of Law, Moscow : State University, 381. [In Russian].

5. Sahaidak, O. (2006). Dyplomatychnyi protokol ta etyket. [Diplomatic protocol and etiquette]. Kyiv : Znannia, 380. [In Ukrainian].

6. Sardachuk, P., Kulyk, O. (2001). Dyplomatychne predstavnytstvo : orhanizatsiia i formy roboty. [Diplomatic representation: organization and forms of work]. Kyiv: Ukraina [Ukraine], 176. [In Ukrainian].

7. Safonov, M. (2007). Kitayskii yazyk i kitayskaia pismennost : kurs lektsyi. [Chinese 
language and Chinese script]. Moscow: AST, East-West, 640. [In Russian].

8. Burhanudeen, H. (2006). Diplomatic language: an insight from speeches used in international diplomacy. Journal of Southeast Asia Social Sciences and Humanities "Akademika". Vol. 67. No 1. P. 37-51. [In English].

9. Crystal, D. (2003). Front matter. In English as a Global Language. N. Y.:
Cambridge University Press, 224. [In English].

12. Felix K, Ameka. (1987). A comparative analysis of linguistic routines in two languages: English and ewe. Journal of Pragmatics. No. 11 (3). P. 299-326. [In English].

10.Stanko, Nick. (2001). Use of language in diplomacy. URL: https://www.diplomacy.edu/ sites/default/files/Language_Diplomacy_Chapter2. PDF

\title{
ПОРІВНЯЛЬНИЙ АНАЛІЗ МОВ В ГАЛУЗІ МІЖНАРОДНИХ ВІДНОСИН С. Б. Христюк, О. О. Щука
}

\begin{abstract}
Анотація. Дослідження спрямоване на детальне вивчення та порівняльний аналіз міжнародних мов у галузі міжнародних відносин та дипломатії у хронологічній послідовності. Доведено, що в аналізі мов є багато змінних, які необхідно глибоко врахувати; найголовнішими є однорідність чи неоднорідність структури населення, культурна спадщина держави та культура мови, що вивчається, різні техніки та стратегії навчання. Дослідження підкреслює той факт, що міжнародні відносини виникли в X - IX століттях до нашої ери $i$ розвивалися досить довго $i$ динамічно; причиною їх швидкого розвитку була потреба у продовольстві та торгівлі рабами. Згодом дипломатія стала інструментом мирного вирішення конфрліктів. Міжнародні відносини розпочались у Греції та Римі, а першою мовою для ведення переговорів була латинська, однак, слід визнати, що сама мова часто була причиною непорозумінь та конфліктів. У якийсь момент вона була замінена на французьку через наполеонівські територіальні захоплення, а згодом на англійську після Паризької мирної конфреренції, на якій англійська та фрранцузька були зрівняні в правах. На засіданні ООН було затверджено кілька міжнародних мов - англійську, фрранцузьку, іспанську, російську та китайську, але вони вважаються лише міжнародними.

Безперечно, дипломатична мова - це велике мистецтво говорити, писати та вирішувати спірні проблеми. Порівнюючи кількість людей та мовне значення, можна зробити висновок, що носії мови не роблять мову міжнародною. Легкість вивчення та схожість з іншими мовами - це відмінні риси, необхідні для того, щоб набути статусу міжнародної мови. Варто зазначити, що простота вивчення мови, а також менталітет мовців не впливають безпосередньо на соціальну значимість мови. Варто відзначити, що глобальна карта мовного впливу має ієрархічну структуру: центральна вісь комунікацій - англійська, оточена центрами другого порядку: німецькою, фрранцузькою, іспанською, російською та португальською.

Вважається, що найдавнішим письмовим договором був договір, укладений у 1296 р. до н.е. між фрараоном Рамзесом II та королем Хатгушилом III. Дане дослідження визначило комунікацію та міжнародні відносини як спільні знаменники та дійшло висновку, що дипломатична мова характеризується не тільки фрактом точності опису, поглибленим аналізом державної політики та дій, але також точними та короткими формулюваннями.
\end{abstract}

Ключові слова: порівняльний аналіз, міжнародна мова, міжнародні відносини, дипломатична мова, переговори, точність, характерні риси. 